Systematic Review

\title{
e An Update of the Appraisal of the Accuracy of Thoracic Discography as a Diagnostic Test for Chronic Spinal Pain
}

\author{
Vijay Singh, MD¹, Laxmaiah Manchikanti, MD², Obi Onyewu, MD², \\ Ramsin M. Benyamin, MD4, Sukdeb Datta, MD5, Stephanie Geffert, MLIS6, \\ Allan T. Parr, $\mathrm{MD}^{7}$ and Frank J.E. Falco, $\mathrm{MD}^{8}$
}

From: ' Spine Pain Diagnostics Associates, Niagara, WI; ${ }^{2}$ Pain Management Center of

Paducah, Paducah, KY, and University of Louisville, Louisville, KY; 3,6,8 Mid Atlantic Spine \& Pain Physicians of Newark, Newark,

DE, and 3,6,8 Temple University Hospital, Philadelphia, PA; ${ }^{4}$ Millennium Pain Center, Bloomington, IL, and University of Illinois, Urbana-Champaign, IL. ${ }^{5}$ Laser Spine \& Pain Institute New York, NY; and PPremier Pain Center, Covington, LA

Additional Author Affiliations on Page E768.

Disclaimer: There was no external funding in preparation of this manuscript.

Conflict of Interest: None

Disclosures: Dr. Benyamin is a consultant with Bioness and Nevro, serves on the advisory boards of Vertos Medical and Nuvo Pharma, teaches/lectures for Vertos Medical, Boston Scientific, Neurotherm, and Bioness, and receives research/grants from Alfred

Mann Foundation, Teknon Foundation,

Spinal Restoration, Inc., Bioness, Boston Scientific, Vertos Medical, Medtronic, Kimberly Clarke, Epimed, BioDelivery

Sciences International, Inc., Theravance, Mundipharma Research, Cephalon/Teva, AstraZeneca, and Purdue Pharma, LP. Dr. Datta receives research support from Sucampo Pharmaceuticals and an honorarium from Smith and Nephew Dr. Falco is a consultant for St. Jude Medical Inc. and Joimax Inc.

Address Correspondence: Vijay Singh, MD Spine Pain Diagnostics, S.C. 1601 Roosevelt Road

Niagara, Wisconsin 54151

E-mail: vj@wmpnet.net

Manuscript received: 10/02/2012 Accepted for publication: 10/11/2012

Free full manuscript: www.painphysicianjournal.com
Background: Even though the prevalence of thoracic pain has been reported to be $13 \%$ of the general population and up to $22 \%$ of the population in interventional pain management settings, the role of thoracic discs as a cause of chronic thoracic and extrathoracic pain has not been well studied. The intervertebral discs, zygapophysial or facet joints, and other structures including the costovertebral and costotransverse joints have been identified as a source of thoracic pain.

Study Design: A systematic review of provocation thoracic discography.

Objective: To systematically assess and update the quality of clinical studies evaluating the diagnostic accuracy of provocation thoracic discography.

Methods: A systematic review of the literature was performed to assess the diagnostic accuracy of thoracic discography with respect to chronic, function limiting, thoracic or extrathoracic pain.

The available literature on thoracic discography was reviewed. A methodological quality assessment of included studies was performed using Quality Appraisal of Reliability Studies (QAREL).

The level of evidence was classified as good, fair, and limited (or poor) based on the quality of evidence developed by the U.S. Preventive Services Task Force (USPSTF).

Data sources included relevant literature identified through searches of PubMed and EMBASE from 1966 to June 2012, and manual searches of the bibliographies of known primary and review articles.

Results: The evidence and clinical value of thoracic provocation discography is limited (poor) with a paucity of evidence, with only 2 studies meeting inclusion criteria.

Limitations: The limitation of this study continues to be the paucity of literature.

Conclusion: Based on the available evidence for this systematic review, due to limited evidence, thoracic provocation discography is rarely recommended for the diagnosis of discogenic pain in the thoracic spine, if conservative management has failed and facet joint pain has been excluded.

Key words: Thoracic pain, chest wall pain, intervertebral disc, thoracic intervertebral disc, thoracic disc herniation, discogenic pain, thoracic provocation discography, falsepositive response, diagnostic accuracy

Pain Physician 2012; 15:E757-E776 
T he lifetime prevalence of spinal pain has been reported as $54 \%$ to $80 \%$; however, the proportion of patients suffering from chronic upper or mid back pain secondary to thoracic disorders is relatively small. The most common spinal regions studied are the lumbar and cervical spine, due to their strong and well-defined associations with pain conditions, work-related injuries, intervertebral disc degenerations, headaches, psychosocial disturbances, and expenses associated with managing these problems (1). It is not only that the thoracic spine has received less attention in terms of clinical, genetic, and epidemiologic research compared to the lumbar and cervical spine, it also has been assumed that the low prevalence of thoracic spinal pain is secondary to relative immobility in support of the thoracic region in contrast to other regions of the spine (1-7). However, pain experienced in the thoracic spine can be equally disabling, imposing similar burdens on the individual, community, and workforce (8-11). The spinal pain experienced in the region of the thoracic spine may arise from a number of sources including thoracic and cervical spinal structures, the thorax, and the gastrointestinal, cardiopulmonary, and renal systems (12-16). In addition, the thoracic spine is a common site for inflammatory, degenerative, metabolic, infective, and neoplastic conditions which may also contribute to pain and disability (15). Even though the limited research on prevalence and risk factors for thoracic spinal pain likely reflects the belief that the clinical and public health significance of thoracic spinal pain is less compared to other spinal levels, it has been argued that thoracic spinal pain should be considered as a discrete and important clinical entity, independent of pain experienced in other areas of the spine (11). In addition, in young adults, thoracic spinal pain is common and disabling with increasing incidence with age during adolescence $(11,17)$. Even though the majority of the thoracic spinal pain and dysfunction may be associated with vertebral fractures (18-21), and hyperkyphosis arising from vertebral bone loss (22), ankylosing spondylitis (23), osteoarthritis (24), and Scheuermann's disease (25), a significant proportion of patients with thoracic pain may suffer with degenerative disorders of the thoracic spine (26). Similar to the lumbar spine, degenerative signs identified in the thoracic spine with imaging modalities are not necessarily associated with pain, suggesting that non-specific thoracic spinal pain is highly prevalent $(12,27-30)$. The emerging evidence suggests that thoracic spinal pain significantly impacts function $(1-11,16,29,30)$. This is also evidenced by the proportion of patients presenting to interventional pain management settings with thoracic pain (31-41), which shows a variable presence of $3 \%$ to $22 \%$. Linton et al (5) estimated that pain in the general population has a prevalence of $15 \%$ in the thoracic area, in contrast to $56 \%$ in the low back, and $44 \%$ in the neck. Briggs et al (3) in a systematic review of 33 studies meeting the inclusion criteria evaluated prevalence, incidence, and associated factors of thoracic spinal pain in the general population. They showed that thoracic spinal pain was significantly associated with concurrent musculoskeletal pain, along with the following factors: growth, physical, lifestyle, social, backpack, postural, psychological, and environmental. The biopsychosocial association was limited in the available literature. This systematic review showed that thoracic spinal prevalence data ranged from $3.5 \%$ to $34.8 \%$ of one-year prevalence and $15.6 \%$ to $19.5 \%$ of lifetime prevalence with a point prevalence of $4 \%$ to $72 \%$. In another literature review, Briggs et al (4) published the results of prevalence and associated factors for thoracic spine pain in the adult working population. They identified 52 studies. Prevalence varied with the occupational group and time period. The one-year prevalence of thoracic spinal pain ranged from $3 \%$ to $55 \%$, with most occupational groups having medians around $30 \%$. Leboeuf-Yde et al $(2,16)$ reported the prevalence of mid back pain at $13 \%$ with significant impact on quality of life.

Even though the thoracic spine has not been studied specifically, it appears that pain generators follow the same pattern as the lumbar spine. Kuslich et al (42) identified intervertebral discs, facet joints, ligaments, fascia, muscles, and nerve root dura as tissues capable of transmitting pain in the low back. Similarly, chronic thoracic or chest wall pain may also be transmitted by intervertebral discs, facet joints, ligaments, fascia, muscles, and nerve root dura, the tissues capable of transmitting pain in the mid back and upper back (33). Chronic, persistent thoracic and chest wall pain, and rare radicular pain may be secondary to disc herniation, discogenic pain, spinal stenosis, or post thoracic surgery syndrome. Furthermore, thoracic facet joints have been shown to be responsible for a significant proportion of pain in the thoracic spine $(32,34,39,40)$. A diagnosis of the structures causing pain is crucial in providing appropriate treatment. Recent health care policy decisions have focused on increasing interventions in managing spinal pain (43-61). However, while facet joint pain has been shown to be significant among a proportion 
of patients responding to epidural steroid injections after failure of facet joint pain, symptomatic thoracic disc herniation is an uncommon condition, accounting for approximately 5 of every 1,000 disc herniations encountered in the clinical setting (60). The majority of thoracic disc herniations are asymptomatic (27), with radicular chest pain being the most common presenting complaint. Overall, very few patients require invasive treatment and most are conservatively treated, returning to their prior level of activity (62). However, a small proportion of cases require interventional techniques or surgical interventions, similar to the cervical and lumbar spine (54-59). Controlled diagnostic interventions have been described in the cervical and lumbar regions with good evidence in the diagnosis of facet joint pain and sacroiliac joint pain, and fair evidence in the diagnosis of lumbar discogenic pain (32-34,40,41,63-71). However, with studies in the thoracic spine studies being very few and far between, the diagnosis of thoracic facet joint pain appears to be fair (40), whereas that of discogenic pain with provocation discography, diagnosis was poor with limited evidence (41).

Provocation discography as performed today was first described in 1948 by Lindblom (72) when he used the term "diagnostic disc puncture." This procedure provisionally replaced oil-contrast myelography described by Dandy (73) in 1929 for the diagnosis of a herniated disc as a cause of radicular pain. During the "herniated disc" era, both axial and referred radicular pain was thought to be due to a herniated disc compressing neural elements (71). It is well known that Mixter and Barr (74) were the first to create widespread interest in the disc as a source of pain in American literature with their 1934 hallmark description of the herniated nucleus pulposus. However, soon after, Mixter and Ayers (75) in 1935 demonstrated that radicular pain could occur without disc herniation. Since then, numerous investigators $(27,71,72,76-120)$ have described pain syndromes emanating from intervertebral discs that are not associated with evidence of the mechanical compression of neural structures. Consequently, internal disc derangement without a specific disc herniation has assumed a major role as a cause of non-specific spinal pain.

Discography has mainly been used as an imaging tool over the years and has been considered to be superior to radiographs, myelography, magnetic resonance imaging (MRI), and computed axial tomography (CT) scanning in imaging intervertebral disc morphology $(41,43,68-71,82,109,110)$. Advances in CT and MRI scanning have added to the knowledge of disc pathol- ogy, structural abnormalities such as degenerative disc changes, herniations, associated end plate changes, and annular tears. There are no definitive tests for the diagnosis of discogenic pain, even in the lumbar and cervical spine. Structural abnormalities are present in patients asymptomatic of spinal pain, thus increasing the importance of discography as the most specific and sensitive test to assess if a disc is painful $(41,68,69,100,104-107,112-114)$. Discography continues to be the criterion standard $(96,98,110,111)$ to determine whether or not a particular disc is painful, irrespective of the evidence or lack thereof for degenerative changes utilizing other imaging modalities. The appropriate performance and diagnostic value of lumbar discography, and, to a somewhat lesser extent, cervical discography, has been extensively documented, practiced, and refined over the past 6 decades since its first descriptions in the 1940s. However, thoracic discography continues to be in its nascent stages of clinical application, specifically in the arena of evidencebased medicine, with the first descriptions of thoracic discography appearing in 1975 (87), approximately 30 years after the description of lumbar discography (72).

In 1975, Simmons and Segil (87) described thoracic discography and nucleography in the evaluation of a man with mid-thoracic radicular pain with a diagnosis of a posterior annular tear that reproduced his thoracic symptoms. In 1994, Schellhas et al (88) published a retrospective review of 100 outpatient thoracic discographies performed on patients whose MRI findings revealed thoracic disc degeneration. In 1999, Wood et al (90) published a prospective study of MRI and thoracic discography in asymptomatic and symptomatic individuals. Over the past few decades, thoracic discography has been used as a safe procedure by skilled interventionalists, with the main purpose being to precisely identify and localize the disc level or levels that are the source of chronic thoracic spinal pain.

The Task Force on Taxonomy of Classification of Chronic Pain in 1994 described criteria for the diagnosis of discogenic pain (112-114). The Task Force (112) defined thoracic discogenic pain as thoracic spinal pain, with or without referred pain. The key diagnostic criteria of thoracic discogenic pain is that the patient's pain must be shown conclusively to stem from an intervertebral disc by provocation discography of the putatively symptomatic disc that reproduces the patient's accustomed pain, and with provocation of at least 2 adjacent intervertebral discs that clearly do not reproduce the patient's pain, and provided that the pain 
cannot be ascribed to some other source innervated by the same segments that innervate the putatively symptomatic disc. The Task Force (112) cautioned that thoracic discography alone is insufficient to conclusively establish a diagnosis of discogenic pain because of the propensity for false-positive responses, either because of apprehension on the part of the patient or because of the coexistence of a separate source of pain within the segment under investigation.

Degeneration of the thoracic disc, along with endplate irregularities and changes due to osteophyte formation, are common findings $(99-101,116)$. Three systematic reviews evaluating the role of provocation discography in the diagnosis of spinal pain have presented limited evidence supporting the role of discography in identifying the subset of patients with thoracic discogenic pain $(41,110,111)$. Furthermore, multiple concerns have been raised in regard to the reported high false-positive rate, the lack of concordance, potential confounding factors, and safety of controlled diagnostic blocks (68-71,76-78,110,111,116-120). In a systematic review of lumbar provocation discography in asymptomatic subjects with a meta-analysis of falsepositive rates, Wolfer et al (71), after extensive evaluation, concluded that the strength of evidence is Level II-2 based on the USPSTF criteria (121) and the criteria for assessment of accuracy of diagnostic studies (122). Singh et al (41) in determining the accuracy of thoracic discography in the evaluation of chronic thoracic pain concluded that the clinical value of thoracic provocation discography was limited Level II-3 with 2C/weak recommendation derived from low quality or very low quality evidence, indicating that other alternatives may be equally reasonable.

In this systematic review, we sought to update the current evidence of provocation discography (41) in the diagnosis of thoracic discogenic pain.

\subsection{Methods}

\subsection{Definition and Criteria}

The International Association for the Study of Pain (IASP) criteria (112) for thoracic discogenic pain includes reproduction of a patient's typical pain with disc stimulation, with a failure to provoke pain in 2 adjacent intervertebral discs through injection. In addition, the pain cannot be ascribed to some other source innervated by the same segments that innervate the putatively symptomatic disc.
The methodology utilized in this systematic review followed the review process derived from evidencebased systematic reviews of diagnostic accuracy studies (123-136).

\subsection{Criteria for Considering Studies for the Review}

\subsubsection{Types of Studies}

Diagnostic accuracy studies of thoracic provocation discography.

\subsubsection{Types of Participants}

Participants of interest were adults aged at least 18 years with chronic mid and/or upper back pain and of at least 3 months duration.

Participants must have failed previous pharmacotherapy, exercise therapy, etc., prior to discography.

\subsubsection{Types of Interventions}

The interventions were thoracic provocation discography.

\subsubsection{Types of Outcome Measures}

- The primary outcome parameter was pain provocation with or without control discs.

- At least 2 of the review authors independently, in an unblinded standardized manner, assessed the outcomes measures. A third author and consensus resolved any disagreements between reviewers.

\subsection{Literature Search}

Searches were performed from the following sources without language restrictions:

1. PubMed from 1966 www.ncbi.nlm.nih.gov/sites/entrez?db=pubmed

2. EMBASE from 1980 www.embase.com/

3. Cochrane Library www.thecochranelibrary.com/view/0/index.html

4. U.S. National Guideline Clearinghouse (NGC) www.guideline.gov/

5. Previous systematic reviews and cross references

6. Clinical Trials clinicaltrials.gov/

The search period was from 1966 through June 2012. 


\subsection{Search Strategy}

The search strategy emphasized chronic thoracic pain and diagnostic interventional techniques with special emphasis on provocation or discography.

At least 2 of the review authors independently, in an unblinded standardized manner, performed each search. Accuracy was confirmed by a statistician. All searches were combined to obtain a unified search strategy. A third author and consensus resolved any disagreements between reviewers.

\subsection{Data Collection and Analysis}

This systematic review focused only on provocation discography. The population of interest was patients suffering with chronic thoracic pain with or without chest wall pain for at least 3 months. Only the diagnostic accuracy of thoracic discography with respect to chronic thoracic pain was evaluated. Reports without appropriate diagnosis, non-systematic reviews, book chapters, and case reports were excluded.

The quality of each individual article used in this assessment was based on QAREL checklist (Table 1) (126). This checklist has been validated and also utilized in multiple systematic reviews (127). Each study in the final sample of eligible manuscripts was assessed using a 12-item appraisal checklist designed to assess the quality and applicability of studies. The face validity of these checklists was established by consultation with methodology experts (126) and comparison with quality appraisal checklists used in other systematic reviews examining diagnostic reliability (128-132). This checklist was also developed in accordance to the Standards for the Reporting Studies of Diagnostic Accuracy Studies (STARD) (124), and the Quality Assessment of Diagnostic Accuracy Studies (QUADAS) $(124,125)$ appraisal tool. Studies were not given an overall numeric quality score; instead each item was considered separately and graded as "yes," "no," "unclear," or "not applicable."

\subsubsection{Selection of Studies}

- In an unblinded, standardized manner, 2 review authors screened the abstracts of all identified studies against the inclusion criteria.

- All articles with possible relevance were then retrieved in full text for a comprehensive assessment of internal validity, quality, and adherence to inclusion criteria.

Table 1. Quality Appraisal of Diagnostic Reliability (QAREL) checklist.

\begin{tabular}{|c|c|c|c|c|}
\hline Item & Yes & No & Unclear & $\mathbf{N} / \mathbf{A}$ \\
\hline \multicolumn{5}{|c|}{$\begin{array}{l}\text { 1. Was the test evaluated in a spectrum of subjects representative of patients who would normally } \\
\text { receive the test in clinical practice? }\end{array}$} \\
\hline \multicolumn{5}{|c|}{$\begin{array}{l}\text { 2. Was the test performed by examiners representative of those who would normally perform the test } \\
\text { in practice? }\end{array}$} \\
\hline \multicolumn{5}{|c|}{ 3. Were raters blinded to the reference standard for the target disorder being evaluated? } \\
\hline \multicolumn{5}{|l|}{ 4. Were raters blinded to the findings of other raters during the study? } \\
\hline \multicolumn{5}{|l|}{ 5. Were raters blinded to their own prior outcomes of the test under evaluation? } \\
\hline \multicolumn{5}{|l|}{ 6. Were raters blinded to clinical information that may have influenced the test outcome? } \\
\hline \multicolumn{5}{|c|}{ 7. Were raters blinded to additional cues, not intended to form part of the diagnostic test procedure? } \\
\hline \multicolumn{5}{|l|}{ 8. Was the order in which raters examined subjects varied? } \\
\hline \multicolumn{5}{|l|}{ 9. Were appropriate statistical measures of agreement used? } \\
\hline \multicolumn{5}{|l|}{ 10. Was the application and interpretation of the test appropriate? } \\
\hline \multicolumn{5}{|c|}{$\begin{array}{l}\text { 11. Was the time interval between measurements suitable in relation to the stability of the variable } \\
\text { being measured? }\end{array}$} \\
\hline \multicolumn{5}{|l|}{ 12. If there were dropouts from the study, was this less than $20 \%$ of the sample. } \\
\hline TOTAL & & & & \\
\hline
\end{tabular}

Lucas N, Macaskill P, Irwig L, Moran R, Bogduk N. Reliability of physical examination for diagnosis of myofascial trigger points. Clin J Pain 2008; 25:80-89 (126). 


\subsubsection{Inclusion and Exclusion Criteria}

The following are the inclusion and exclusion criteria:

1. Are the patients described in sufficient detail to allow one to decide whether they are comparable to those who are treated in interventional pain management clinical practices?

A. Setting - office, hospital, outpatient, inpatient

B. Physician - interventional pain physician, general physician, anesthesiologist, physiatrist, neurologist, rheumatologist, orthopedic surgeon, neurosurgeon, etc.

C. Patient characteristics - duration of pain

D. Non-interventional techniques or surgical intervention in the past

2. Is the intervention described in sufficient detail to enable one to apply its use to patients in interventional pain management settings?
A. Nature of intervention
B. Frequency of intervention
C. Duration of intervention
3. Were clinically relevant outcomes measured?
A. Proportion of pain relief
B. Disorder/specific disability
C. Functional improvement
D. Allocation of eligible and non-eligible patients to return to work
E. Ability to work

\subsubsection{Clinical Relevance}

The clinical relevance of the included studies was evaluated according to 5 questions recommended by the Cochrane Back Review Group (Table 2) $(133,134)$. Each question was scored positive (+) if the clinical relevance item was met, negative $(-)$ if the item was not met, and unclear (?) if data were not available to answer the question.

\subsubsection{Methodological Quality or Validity Assessment}

Each study was evaluated by at least 2 authors for stated criteria. Any disagreements were discussed with a third reviewer. Authors with a perceived conflict of interest for any manuscript were recused from reviewing the manuscript.

Only diagnostic accuracy studies meeting at least $50 \%$ of applicable inclusion criteria were included for analysis. Studies scoring less than $50 \%$ are reported descriptively with critical analysis.

\subsubsection{Data Extraction \& Management}

Two review authors independently, in an unblinded standardized manner, extracted the data from the included studies. Disagreements were resolved by discussion between the 2 reviewers; if no consensus could be reached, a planned third author was called in to break the impasse.

\subsection{Analysis of Evidence}

The analysis of the evidence was performed based on USPSTF criteria as illustrated in Table 3, which has been utilized by multiple authors $(136,137)$.

The analysis was conducted using 3 levels of evidence ranging from good, fair, and limited or poor.

At least 2 of the review authors independently, in an unblinded standardized manner, analyzed the evidence. A third author and consensus resolved any disagreements between reviewers. If there were any conflicts of interest (e.g., with authorship), those reviewers were recused from assessment and analysis.

\subsection{Outcome of the Studies}

Outcome evaluations included the prevalence of thoracic discogenic pain and false-positive results.

Table 2. Clinical relevance questions.

\begin{tabular}{|c|c|c|c|}
\hline & $\mathbf{P}(+)$ & N (-) & $\overline{\mathrm{U} \text { (unclear) }}$ \\
\hline $\begin{array}{l}\text { A) Are the patients described in detail so that one can decide whet } \\
\text { treated practice? }\end{array}$ & & & \\
\hline B) Are the interventions and treatment settings described in sufficie & & & \\
\hline C) Were clinically relevant outcomes measured and reported? & & & \\
\hline D) Is the size of the effect clinically meaningful? & & & \\
\hline E) Do the likely treatment benefits outweigh the potential harms? & & & \\
\hline
\end{tabular}

Scoring adapted and modified from Staal JB, et al. Injection therapy for subacute and chronic low back pain. Cochrane Database Syst Rev 2008; 3:CD001824 (134). 
Table 3. Method for grading the overall strength of the evidence for an intervention.

\begin{tabular}{|l|l||}
\hline Grade & Definition \\
\hline Good & $\begin{array}{l}\text { Evidence includes consistent results from well-designed, well-conducted studies in representative populations that directly } \\
\text { assess effects on health outcomes (at least } 2 \text { consistent, higher-quality RCTs or studies of diagnostic test accuracy). }\end{array}$ \\
\hline Fair & $\begin{array}{l}\text { Evidence is sufficient to determine effects on health outcomes, but the strength of the evidence is limited by the number, } \\
\text { quality, size, or consistency of included studies; generalizability to routine practice; or indirect nature of the evidence on health } \\
\text { outcomes (at least one higher-quality trial or study of diagnostic test accuracy of sufficient sample size; } 2 \text { or more higher-quality } \\
\text { trials or studies of diagnostic test accuracy with some inconsistency; at least } 2 \text { consistent, lower-quality trials or studies of } \\
\text { diagnostic test accuracy, or multiple consistent observational studies with no significant methodological flaws). }\end{array}$ \\
\hline $\begin{array}{l}\text { Limited or } \\
\text { Poor }\end{array}$ & $\begin{array}{l}\text { Evidence is insufficient to assess effects on health outcomes because of limited number or power of studies, large and } \\
\text { unexplained inconsistency between higher-quality trials, important flaws in trial design or conduct, gaps in the chain of } \\
\text { evidence, or lack of information on important health outcomes. }\end{array}$ \\
\hline
\end{tabular}

Adapted and modified from methods developed by U.S. Preventive Services Task Force (64-66,68-70,136,137).

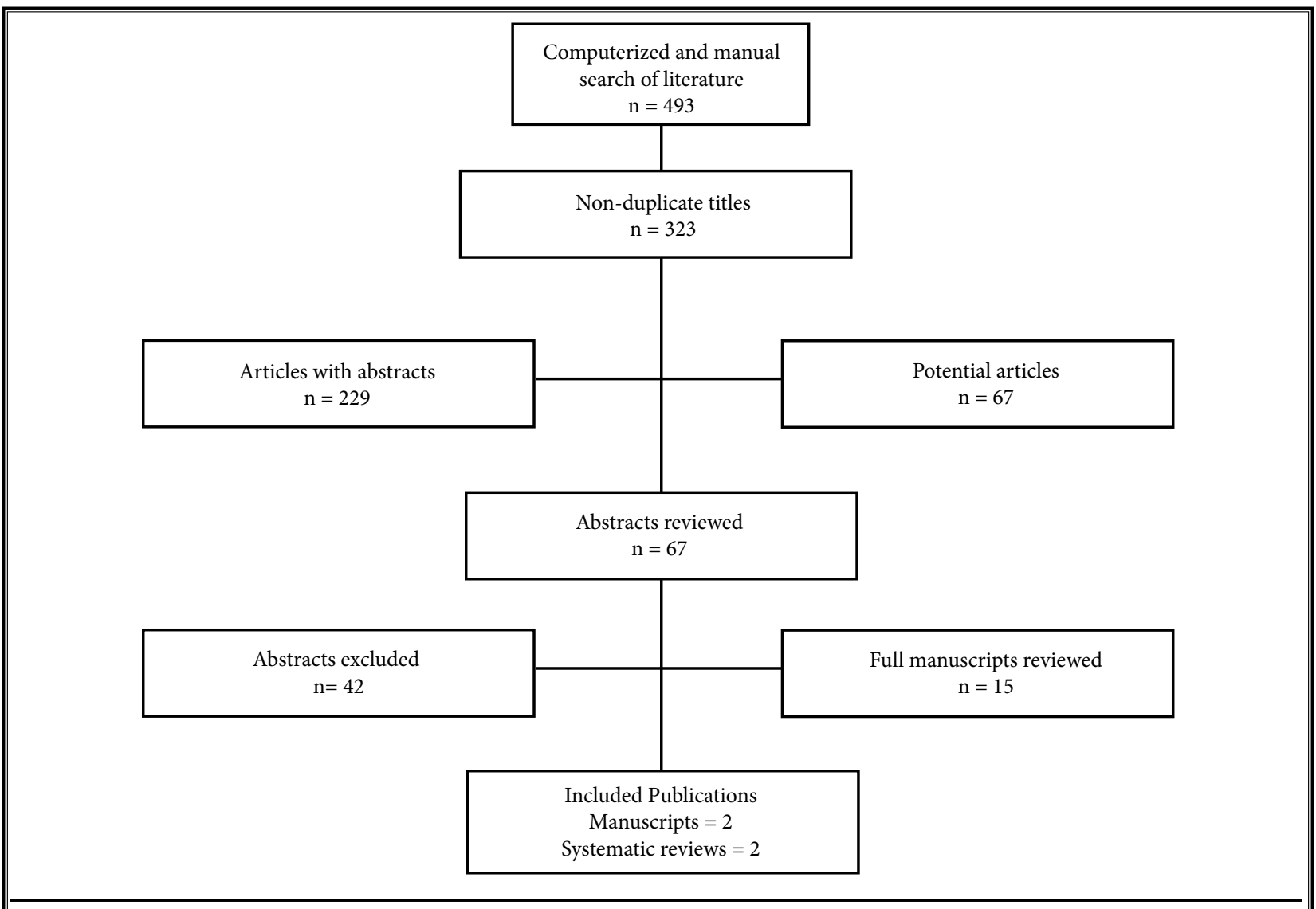

Fig. 1. The flow diagram illustrating published literature evaluating thoracic provocation discography.

\subsection{Results}

Figure 1 shows a flow diagram of study selection. There were 2 studies considered for inclusion $(88,90)$.

\subsection{Clinical Relevance}

Of the 2 studies assessed for clinical relevance, both studies met criteria scoring of 5 out of 5 . Table 4 illustrates the assessment of clinical relevance. 
Table 4. Clinical relevance of included studies.

\begin{tabular}{|l|c|c|c|c|c|c|}
\hline Manuscript Author(s) & $\begin{array}{c}\text { A) Patient } \\
\text { description }\end{array}$ & $\begin{array}{c}\text { B) Description of } \\
\text { interventions and } \\
\text { treatment settings }\end{array}$ & $\begin{array}{c}\text { C) Clinically } \\
\text { relevant } \\
\text { outcomes }\end{array}$ & $\begin{array}{c}\text { D) Clinical } \\
\text { importance }\end{array}$ & $\begin{array}{c}\text { E) Benefits } \\
\text { versus potential } \\
\text { harms }\end{array}$ & $\begin{array}{c}\text { Total Criteria } \\
\text { Met }\end{array}$ \\
\hline Schellhas et al 1994 (88) & + & + & + & + & + & $5 / 5$ \\
\hline Wood et al $1999(90)$ & + & + & + & + & + \\
\hline
\end{tabular}

$+=$ positive; $-=$ negative

Scoring adapted from Staal JB, et al. Injection therapy for subacute and chronic low back pain. Cochrane Database Syst Rev 2008; 3:CD001824 (134).

Table 5. Methodologic quality assessment utilizing Quality Appraisal of Diagnostic Reliability checklist.

\begin{tabular}{|c|c|c|}
\hline & Schellhas et al (88) & Wood et al (90) \\
\hline $\begin{array}{l}\text { 1. Was the test evaluated in a spectrum of subjects representative of patients who would } \\
\text { normally receive the test in clinical practice? }\end{array}$ & + & + \\
\hline $\begin{array}{l}\text { 2. Was the test performed by examiners representative of those who would normally perform } \\
\text { the test in practice? }\end{array}$ & + & + \\
\hline 3. Were raters blinded to the reference standard for the target disorder being evaluated? & - & - \\
\hline 4. Were raters blinded to the findings of other raters during the study? & - & - \\
\hline 5. Were raters blinded to their own prior outcomes of the test under evaluation? & - & - \\
\hline 6. Were raters blinded to clinical information that may have influenced the test outcome? & NA & NA \\
\hline $\begin{array}{l}\text { 7. Were raters blinded to additional cues, not intended to form part of the diagnostic test } \\
\text { procedure? }\end{array}$ & - & - \\
\hline 8. Was the order in which raters examined subjects varied? & + & + \\
\hline 9. Were appropriate statistical measures of agreement used? & - & - \\
\hline 10. Was the application and interpretation of the test appropriate? & + & + \\
\hline $\begin{array}{l}\text { 11. Was the time interval between measurements suitable in relation to the stability of the } \\
\text { variable being measured? }\end{array}$ & NA & NA \\
\hline 12. If there were dropouts from the study, was this less than $20 \%$ of the sample. & + & + \\
\hline TOTAL & $5 / 10$ & $5 / 10$ \\
\hline
\end{tabular}

Y=yes; $\mathrm{N}=$ no; $\mathrm{U}=$ unclear; $\mathrm{N} / \mathrm{A}=$ not applicable

\subsection{Methodological Quality Assessment}

A methodological quality assessment of diagnostic accuracy studies meeting inclusion criteria was carried out utilizing QAREL criteria as shown in Table 5. Studies achieving $50 \%$ or higher scores were included. Scores of $67 \%$ or higher were considered to be high quality, $\geq 50 \%$ were considered to be moderate quality, and studies scoring less than $50 \%$ were considered to be of poor quality and excluded)

There were 2 studies evaluating provocation discography $(88,90)$.

\subsection{Study Characteristics}

In 1994, Schellhas et al (88) published their experience with thoracic discograms performed on 100 outpatients by a retrospective analysis. After MRI, clinically suspect, morphologically abnormal thoracic discs and at least one nearby controlled level disc were injected with either non-ionic contrast or saline, filmed, and individually described by the patient as concordant versus non-concordant relative to clinical pain, and rated in pain intensity on a scale of 0 to 10 . The results illustrated that discs with annular tears, intrinsic degeneration, 
and vertebral body endplate infarctions were painful approximately $75 \%$ of the time. They demonstrated a clinical concordance of $50 \%$ with painless control levels. In this series, clinically concordant extraspinal pain such as chest wall, intrathoracic, and upper abdominal pain were frequently provoked with thoracic disc injections. They described non-protruding disc derangements such as may be seen either in active or old juvenile discogenic disease (Scheuermann's disease). Internal disc derangements may be painful and clinically significant with more than $50 \%$ of the painful discs that they studied falling into this category. The authors concluded that thoracic discography can be performed safely by experienced individuals as a reliable tertiary diagnostic procedure to determine if degenerated discs on MRI studies are related to clinical complaints. The shortcomings of this evaluation include it being a retrospective evaluation. They described the technical aspects extensively, even though characteristics of patients' pain patterns were not provided at baseline. Further, a consistent reference standard was not applied. There was no blinded comparison of the test.

Wood et al (90) performed a prospective evaluation. They sought to determine the responses to thoracic discography by asymptomatic and symptomatic individuals. They evaluated 10 adult lifelong asymptomatic volunteers, ages 23 to 45 years, who underwent MRI of the thoracic spine, by a 4-level discography. Provocation responses were graded on a scale of 0 (no sensation) to 10 (extreme pain or pressure), and filmed discs were graded using a modified Dallas scheme. Concomitantly, 10 non-litigious adults, ages 31 to 55 years, experiencing chronic thoracic pain were similarly studied. The results showed the mean pain responses in the asymptomatic volunteers to be $2.4 / 10$. Three discs in the asymptomatic group were intensely painful with scores of $7 / 10,8 / 10$, and $10 / 10$, with all 3 exhibiting prominent endplate irregularities and annular tears typical of thoracolumbar Scheuermann's disease. On discography, 27 of 40 discs were abnormal, with endplate irregularities, annular tears, and/or herniations. They also reported that the 10 discs read as normal on MRI showed annular pathology on discography. In the group with chronic thoracic pain, the average pain response was $6.3 / 10$ ( $P$ $<0.05)$. Of the 48 discs studied, $50 \%$ or 24 were concordantly painful, with a response of $8.5 / 10(P<0.05)$. Seventeen discs had non-concordant pain or pressure, with an average pain score of $4.8 / 10(P<0.05)$ and 5 had no response. On MRI, 21 of the 48 discs appeared normal, whereas on discography, only 10 were judged as normal. They concluded that on discography, thoracic discs with prominent Schmorl's nodes may be intensely painful, even in lifelong asymptomatic individuals, but the pain is unfamiliar or non-concordant. They also concluded that thoracic discography may demonstrate disc pathology not seen on MRI.

Evidence was also provided for the relative lack of reliability of MRI at identifying painful deranged discs (90). They reported a high incidence of relatively painless disc pathology, including annular tears and frank herniations, with discography in both the symptomatic and asymptomatic patients that was missed on MRI. Further, they noted that a general trend toward more painful responses was being observed with greater degrees of pathology, especially with endplate pathology such as Scheuermann's disease. Variability was reported in perceived pain or pressure, even though typically it was on the same side as the disc pathology, whether it was a tear or herniation.

This first ever controlled prospective study in asymptomatic and symptomatic individuals had some deficiencies (90). There were only 10 lifelong asymptomatic volunteers. While they concluded that thoracic discography in the truly asymptomatic individual is not painful, regardless of the degree of pathology observed, they reported 3 of the 40 discs $(7.5 \%)$ as intensely painful with pain of 7,8 , and 10 on a scale of 0 to 10 . However, the 3 of them exhibited prominent endplate changes typical of thoracolumbar Scheuermann's pathology. Two of these painful responses were in one volunteer. Consequently, $20 \%$ of the asymptomatic volunteers reported pain when they had severe Scheuermann's pathology. Once the 3 painful discs or 2 painful patients were removed, the average pain response was less than 2/10. Only one volunteer reported aching muscle-like pain for 48 hours, which resolved quickly at that point with no sequelae. The authors have not provided detailed results with regards to negative contiguous discs, one above and one below, thus, the criteria was limited to only elicitation of concordant pain. Twenty-seven of 49 or $55 \%$ of the discs studied in the symptomatic group were concordant.

\subsection{Validity}

Wood et al (90) evaluated the validity of the concordant pain and the role of false-positive responses. They reported the mean pain response in the asymptomatic volunteers as $2.4 / 10$ even though 3 discs exhibiting prominent endplate irregularities and annular tears typical of thoracolumbar Scheuermann's disease 
were intensely painful. Furthermore, of the 48 discs studied, only 21 appeared normal on MRI and only 10 were judged as normal after provocation discography. The discs which exhibited concordant pain (24 of 48 or $50 \%$ ) exhibited a pain response of $8.5 / 10$, statistically higher pain levels than the 17 discs that exhibited non-concordant pain pressure with an average pain of 4.8/10, and 5 discs with no pain response at all.

Schellhas et al (88) evaluated concordant pain and also at least one nearby controlled level disc. They demonstrated clinical concordance in approximately $50 \%$ of the discs, with controlled levels being painless.

\subsection{Prevalence}

The prevalence of thoracic discogenic pain has not been determined.

\subsection{False-positive Rates}

Utilizing the data by Wood et al (90), it appears that the false-positive rate with thoracic discograms is 0 if a pain response of 7 or above is considered as positive with concordant pain with negative contiguous discs. When endplate irregularities and annular tears are taken into consideration as shown in the asymptomatic patients, even though the mean response in volunteers was 2.4/10, 3 discs in 2 patients were intensely painful with scores ranging from 7 to 10 of 10 . Consequently, in patients with severe pathology, pain may be produced in $20 \%$ of the patients. Considering the clinical realities which dictate provocation thoracic discography to be performed only in symptomatic patients, utilizing the IASP criteria (112), and that these positive patients may have been dormant and fallen within the range of the prevalence of discogenic pain, it is considered that the false-positive rate with thoracic provocation discography is low.

Schellhas et al (88) evaluated concordant pain with a controlled disc at least at one level. They demonstrated a clinical concordance of $50 \%$ with painless control levels. They also concluded that they were able to determine whether observed disc pathology related to clinical pain complaints in every patient. In isolated cases in which patient uncertainty existed after thorough questioning about pain-pressure concordance at individual disc levels, the authors interpreted the response at that level as to be either indeterminate or non-concordant. They showed that in these cases, at least one other disc was clearly concordant; hence, the total examination was considered to be conclusive. In this study, they evaluated a total of 306 discs. Custom- arily they studied consecutive discs including more than one normal-appearing control level disc if necessary (138). Morphologically deranged thoracic discs produced more painful responses compared with normalappearing control levels, even though these responses were not necessarily concordant relative to the pain being investigated $(97,139,140)$. Based on the results of this study, it appears that false-positive rates are low when discography is performed appropriately using a concordance of pain and negative control discs.

Fluke (141) criticized the report on its definition of reliable, high degree of accuracy, and Schellhas et al's conclusion that they were able to determine whether observed disc pathology related to clinical pain in every patient. Fluke contended that Schellhas et al failed to provide the data necessary to determine whether their techniques were accurate or not, because truepositive, true-negative, and false-negative rates were not reported.

In reply, Schellhas (142) referred to the formal prospective investigations of false-positive rates in the lumbar spine $(140,143)$. Schellhas also pointed out that discography results do not provide an "excuse to operate."

\subsection{Analysis of Evidence}

Based on the USPSTF criteria, the evidence is considered at 3 levels - good, fair, and limited or poor. The evidence based on this analysis is limited due to only 2 moderate quality studies with no recent literature available.

\subsection{Discussion}

This systematic review provides limited evidence for using provocation discography to identify patients with chronic thoracic discogenic pain. There are no prevalence or false-positive data available. Considering that thoracic facet joint pain is present in $34 \%$ to $48 \%$ of patients with chronic non-specific function-limiting mid back and upper back pain with false-positive rates of $42 \%$ to $58 \%$ with a single block $(32,33,40)$, it appears that thoracic discogenic pain may be present in at least an equal proportion of patients. Chronic lumbar discogenic pain has been reported in $26 \%$ to $39 \%$ of patients regardless of internal disc disruption $(80,81)$. The prevalence of chronic discogenic neck pain has been reported as $16 \%$ and possibly $41 \%$ of the patients (82). Singh et al (41) in a 2008 systematic review determined the accuracy of thoracic discography in an evaluation of chronic thoracic pain utilizing 2 studies $(88,90)$ with 
evidence which was shown as limited or Level II-3 with a weak recommendation derived from low quality or very low quality studies, indicating that other alternatives may be equally reasonable. They also noted that the drawbacks of the evaluation on thoracic discography were that only 2 studies were available, both from the same group of authors, with the last study being published in 1999, and there have been no subsequent attempts by the same authors or others to replicate or confirm previously published results. There also was not any literature showing the effectiveness of therapeutic modalities based on the results of discography.

The same problems from the previous systematic review (41) were experienced in the present systematic review. There is continued paucity of the literature and methodological challenges in assessing the accuracy of thoracic provocation discography also continue. Furthermore, there have only been 2 studies evaluating the value of discography $(88,90)$ and there have not been any new studies since 1999 . Since the previous publication (41), however, 3 reports have been published showing the management techniques of thoracic discogenic pain with nucleoplasty, intradiscal biaculoplasty, and laser disc decompression $(54,55,57)$. For percutaneous laser disc decompression for thoracic disc disease, patients underwent discography prior to percutaneous laser disc decompression. These are all case reports, with the largest one being the laser disc decompression (57) with 10 patients. These do not provide any substantial support to provocation discography; however, such emerging studies may in the future provide appropriate evidence.

The issues related to criterion or gold standard and methodologic challenges continue in this evaluation. For this evaluation we utilized new methodologic quality assessment criteria as developed by Lucas et al (126) that may be similar or superior to QUADAS and others.

There is no gold standard for discogenic pain. A concordantly painful disc with contiguous negative discs was considered as the gold standard for this systematic review. Both the studies $(88,90)$ considered for inclusion in this systematic review were able to describe, in detail, concordant pain, but only one study (88) described a negative disc. The assessment of pain may be considered as a soft measure and has been challenged repeatedly $(71,140,144-155)$. The patients' ability to consistently report pain accurately during discography along with multiple confounding factors has been extensively discussed $(71,156,157)$. There are no studies evaluating the outcomes based on surgical treatments derived from opinions of appropriately performed thoracic provocation discography. A gold standard of tissue biopsy, which is not reliable in the case of degenerative discs, may also be inappropriate as a criterion standard for provocation discography.

The evidence for thoracic discography consists of only 2 studies from the same group of authors. Fluke (141) in response to the study by Schellhas et al (88) wrote that the data presented in this article are not sufficient to support the conclusion that thoracic discography is a "reliable tertiary diagnostic procedure to determine if degenerated discs on MR studies are related to clinical complaints." Fluke criticized that authors failed to define "reliable" as it relates to this study. Moreover, the study was criticized for not providing the data necessary to determine whether their techniques are accurate or not, because true-positive, true-negative, and false negative rates were not reported in this study. However, Fluke (141) felt that thoracic discography is technically feasible and probably safe without providing any significant evidence.

The basic principles for thoracic provocation discography are to determine whether or not a thoracic $\operatorname{disc}(s)$ is the source of a patient's thoracic, chest wall, or upper abdominal pain. Thus, thoracic discography is performed in an attempt to provoke pain with each injection at each designated level. A local anesthetic can be used to anesthetize painful discs to further refine the identification of a concordantly painful disc. If thoracic pain is reproduced during thoracic discography, the disc or discs are responsible for at least part or all of the pain $(112,115)$. If thoracic pain is not reproduced during thoracic discography, then the discs are excluded as potential pain generators. Disc stimulation is analogous to palpation for tenderness $(112,145)$. The rationale for thoracic provocation discography is based on the fact that thoracic discs are innervated and therefore can elicit pain $(97,115,158-165)$. Anatomical studies have demonstrated that intervertebral discs receive an innervation posteriorly from the sinuvertebral nerves, laterally from the vertebral nerves, and anteriorly from the sympathetic trunks $(43,99,112,119,158-168)$. In addition, thoracic discs have been shown to cause chronic upper back and mid back pain $(88,90)$. Discogenic pain has been described to be dull and aching in quality, whereas, neurogenic pain has been described to be lancinating in quality (86). Imaging studies such as radiographs, myelography, CT, CT-myelography, and MRI are inaccurate in determining whether a thoracic disc is responsible for a patient's pain complaints or the 
presence or absence of disc pathology (91). In addition, the patterns for thoracic discogenic pain are expected to be indistinguishable from those of thoracic facet joint pain, as in the lumbar and cervical regions (115118). Even though these pain patterns can be used to indicate the most likely segmental source of pain and, therefore, the levels at which investigations should be focused, these patterns reflect the innervation of the source of the pain, and they do not implicate a particular structure as the source. Thus, it is essential to rule out thoracic facet joint pain prior to embarking on provocation discography. Physical examination will distinguish the source of pain because shear stress applied to the thoracic spine will simultaneously stress not only the disc, but also facet joints.

The criteria developed by IASP (112) have recommended that in order to be valid, thoracic provocation discography must be subjected to anatomical controls. Consequently, the 2 diagnostic criteria for discogenic pain must be met in each and every case. The first criterion is that the provocation of the target disc reproduces the patient's pain. The second criterion is that provocation of adjacent discs does not reproduce the pain. Validity may also be enhanced by appropriate assessment of the pain including location, quality, intensity, and concordance.

The role of placebo and nocebo is also a factor in diagnostic accuracy and treatment effect and has been extensively discussed (169-187). Similarly, role of placebo design, and the effect of injecting various solutions into active and inactive structures may influence patient responses (188-197). Discography may also be associated with multiple adverse effects (198-219).

In summary, extensive research is not currently available regarding the various causes of thoracic pain and the diagnosis of those causes. Some studies $(32,34,69)$ have focused on the prevalence of thoracic facet joint pain, but there are no studies evaluating the prevalence of thoracic discogenic pain. This systematic review provides limited (poor) evidence for thoracic discography as a diagnostic tool.

\subsection{Conclusion}

Based on the present systematic review the strength of evidence is limited (poor) based on the AHRQ USPSTF criteria for the diagnostic accuracy for discography, with a recommendation that the procedure is reserved for rare occasions.

\section{Author Affiliations}

Dr. Singh is Medical Director, Spine Pain Diagnostics Associates, Niagara, WI

Dr. Manchikanti is Medical Director of the Pain Management Center of Paducah, Paducah, KY and Clinical Professor, Anesthesiology and Perioperative Medicine, University of Louisville, Louisville, KY.

Dr. Onyewu is Attending Physician, Mid Atlantic Spine \& Pain Physicians, Newark, DE and Elkton, MD; Faculty, Pain Medicine Fellowship Program, Temple University Hospital, Philadelphia, PA; Adjunct Assistant Professor, Temple University Medical School, Philadelphia, PA.

Dr. Benyamin is the Medical Director, Millennium Pain Center, Bloomington, IL, Clinical Assistant Professor of Surgery, College of Medicine, University of Illinois, Urbana-Champaign, IL

Dr. Datta is Medical Director, Laser Spine \& Pain Institute, New York, NY; and Professorial Lecturer,Mount Sinai School of Medicine, Department of Anesthesiology, New York

Ms. Geffert is Director of Research and Education and Administrative Assistant at Mid Atlantic Spine \& Pain Physicians of Newark, DE and Fellowship Coordinator at Temple University Hospital, Philadelphia, PA

Dr. Parr is Medical Director, Premier Pain Center, Covington, LA

Dr. Falco is Medical Director of Mid Atlantic Spine \& Pain Physicians, DE; Director, Pain Medicine Fellowship Program, Temple University Hospital, Philadelphia, PA and Associate Professor, Department of PM\&R, Temple University Medical School, Philadelphia, PA

\section{Acknowledgments}

The authors thank Pain Physician for permitting to reproduce Singh et al's (41) manuscript from 2008, and the editorial board of Pain Physician for review and criticism in improving the manuscript. The authors also wish to thank Vidyasagar Pampati, MSc, for statistical assistance, Sekar Edem for assistance in the search of the literature, Alvaro F. Gómez, MA, for manuscript review, and Tonie M. Hatton and Diane E. Neihoff, transcriptionists, for their assistance in preparation of this manuscript. 


\section{References}

1. Manchikanti L, Singh V, Datta S, Cohen SP, Hirsch JA. Comprehensive review of epidemiology, scope, and impact of spinal pain. Pain Physician 2009; 12:E35E7o.

2. Leboeuf-Yde C, Nielsen J, Kyvik KO, Fejer R, Hartvigsen J. Pain in the lumbar, thoracic or cervical regions: do age and gender matter? A population-based study of 34,902 Danish twins 20-71 years of age. BMC Musculoskelet Disord 2009; 10:39.

3. Briggs AM, Smith AJ, Straker LM, Bragge $P$. Thoracic spine pain in the general population: Prevalence, incidence and associated factors in children, adolescents and adults. A systematic review. BMC Musculoskelet Disord 2009; 10:77.

4. Briggs AM, Bragge $P$, Smith AJ, Govil $D$, Straker LM. Prevalence and associated factors for thoracic spine pain in the adult working population: A literature review. J Occup Health 2009; 51:177-192.

5. Linton SJ, Halldén K. Can we screen for problematic back pain? A screening questionnaire for predicting outcome in acute and subacute back pain. Clin J Pain 1998; 14:209-215.

6. Anderson R, Meeker WC, Wirick BE, Mootz RD, Kirk DH, Adams A. A metaanalysis of clinical trials of spinal manipulation. J Manipulative Physiol Ther 1992; 15:181-194.

7. Occhipinti E, Colombini D, Grieco A. Study of distribution and characteristics of spinal disorders using a validated questionnaire in a group of male subjects not exposed to occupational spinal risk factors. Spine (Phila Pa 1976) 1993; 18:1150-1159.

8. Edmondston SJ, Singer KP. Thoracic spine: Anatomical and biomechanical considerations for manual therapy. Man Ther 1997; 2:132-143.

9. Austin GP, Benesky WT. Thoracic pain in a collegiate runner. Man Ther 2000; 7:168-172.

10. Briggs AM, Straker LM. Thoracic spine pain in youth: Should we be concerned? Spine Journal 2009; 9:338-339.

11. Wedderkopp N, Leboeuf-Yde C, Andersen LB, Froberg K, Hansen HS. Back pain reporting pattern in a Danish population-based sample of children and adolescents. Spine (Phila Pa 1976) 2001; 26:1879-1883.

12. Australian Acute Musculoskeletal Pain Guidelines Group Evidence-based management of acute musculoskeletal pain.
A guide for clinicians. Brisbane: Australian Academic Press. National Health and Medical Research Council (Australia); 2004.

13. Fruth SJ. Differential diagnosis and treatment in a patient with posterior upper thoracic pain. Phys Ther 2006; 86:254268.

14. Fukui S, Ohseto K, Shiotani M. Patterns of pain induced by distending the thoracic zygapophyseal joints. Reg Anesthesia 1997; 22:332-336.

15. Singer KP. Pathology of the thoracic spine. In: Giles LGF, Singer KP, editor. Clinical Anatomy and Management of Thoracic Spine Pain The Clinical Anatomy and Management of Back Pain Series. Butterworth Heinmann, Oxford, 2000, pp 63-82.

16. Leboeuf-Yde C, Fejer R, Nielsen J, Kyvik $\mathrm{KO}$, Hartvigsen J. Consequences of spinal pain: do age and gender matter? A Danish cross-sectional population-based study of 34,902 individuals 20-71 years of age. BMC Musculoskelet Disord 2011; 12:39.

17. Grimmer K, Nyland L, Milanese S. Repeated measures of recent headache, neck and upper back pain in Australian adolescents. Cephalgia 2006; 26:843-851.

18. Briggs AM, Greig AM, Wark JD. The vertebral fracture cascade in osteoporosis. A review of aetiopathogenesis. Osteoporos Int 2007; 18:575-584.

19. Cockerill WC, Ismail AA, Cooper C, Matthis C, Raspe H, Silman AJ, O'Neill TW. Does location of vertebral deformity within the spine influence back pain and disability? European Vertebral Osteoporosis Study (EVOS) Group. Ann Rheum Dis 2000; 59:368-371.

20. Ettinger B, Black D, Nevitt MC, Rundle AM, Cauley JA, Cummings SR, Genant HK. Contribution of vertebral deformities to chronic back pain and disability. J Bone Miner Res 1992; 7:449-455.

21. Johansson C, Mellstrom D, Rosengren K, Rundgren A. A community based population study of vertebral fractures in 85 year old men and women. Age and Ageing 1994; 23:388-392.

22. Kado DM, Prenovost K, Crandall C. Narrative review: Hyperkyphosis in older persons. Ann Int Med 2007; 147:330-338.

23. Sampaio-Barros PD, Bertolo MB, Kraemer MHS, Neto JFM, Samara AM. Primary ankylosing spondylitis: Patterns of disease in a Brazilian population of 147 patients. J Rheum 2001; 28:560-565.
24. Kramer PA. Prevalence and distribution of spinal osteoarthritis in women. Spine (Phila Pa 1976) 2006; 31:2843-2848.

25. Murray PM, Weinstein SL, Spratt KF. The natural history and long term follow-up of Scheuermann kyphosis. J Bone Joint Surg (American) 1993; 75A:236-248.

26. Dionne $C E$, Bourbonnais $R$, Fremont $P$, Rossignol M, Stock SR, Nouwen A, Larocque I, Demers E. Determinants of "return to work in good health" among workers with back pain who consult in primary care settings: A 2-year prospective study. Eur Spine ] 2007; 16:641-655.

27. Wood KB, Garvey TA, Gundry C, Heithoff KB. Magnetic resonance imaging of the thoracic spine. J Bone Joint Surg Am 1995; 77:1631-1638.

28. Niemeläinen R, Battié $M C$, Gill K, Videman $T$. The prevalence and characteristics of thoracic magnetic resonance imaging findings in men. Spine (Phila Pa 1976) 2008; 33:2552-2559.

29. Hakala P, Rimpela A, Salminen JJ, Virtanen SM, Rimpela M. Back, neck and shoulder pain in Finnish adolescents: National cross sectional surveys. Brit Med J 2002; 325:743-745.

30. Niemelainen R, Videman T, Battie MC. Prevalence and characteristics of upper or mid-back pain in Finnish men. Spine (Phila Pa 1976) 2006; 31:1846-1849.

31. Manchikanti L, Pampati V. Research designs in interventional pain management: Is randomization superior, desirable or essential? Pain Physician 2002; 5:275-284.

32. Manchikanti L, Boswell MV, Singh V, Pampati V, Damron KS, Beyer CD. Prevalence of facet joint pain in chronic spinal pain of cervical, thoracic, and lumbar regions. BMC Musculoskelet Disord 2004; 5:15.

33. Manchikanti L, Boswell MV, Singh V, Derby R, Fellows B, Falco FJ, Datta S, Smith HS, Hirsch JA; ASIPP. Comprehensive review of neurophysiologic basis and diagnostic interventions in managing chronic spinal pain. Pain Physician 2009; 12:E71-E120.

34. Manchukonda R, Manchikanti KN, Cash KA, Pampati V, Manchikanti L. Facet joint pain in chronic spinal pain: An evaluation of prevalence and false-positive rate of diagnostic blocks. J Spinal Disord Tech 2007; 20:539-545.

35. Manchikanti L, Pampati V, Fellows B, Beyer CD, Damron KS, Barnhill RC, Burks TA. Characteristics of chronic low 
back pain in patients in an interventional pain management setting: A prospective evaluation. Pain Physician 2001; 4:131-142.

36. Manchikanti L, Cash KA, McManus CD Pampati V, Benyamin RM. A preliminary report of a randomized double-blind, active controlled trial of fluoroscopic thoracic interlaminar epidural injections in managing chronic thoracic pain. Pain Physician 2010; 13:E357-E369.

37. Manchikanti L, Singh V, Falco FJE, Cash KA, Pampati V, Fellows B. Comparative effectiveness of a one-year follow-up of thoracic medial branch blocks in management of chronic thoracic pain: A randomized, double-blind active controlled trial. Pain Physician 2010; 13:535-548.

38. Manchikanti L, Singh V, Falco FJE, Cash KA, Pampati V, Fellows B. The role of thoracic medial branch blocks in managing chronic mid and upper back pain: A randomized, double-blind, activecontrol trial with a 2-year follow-up. Anesthesiol Res Pract 2012; 2012:585806.

39. Benyamin RM, Wang VC, Vallejo R, Singh V, Helm S II. A systematic evaluation of thoracic interlaminar epidural injections. Pain Physician 2012; 15:E497E514.

40. Atluri S, Singh V, Datta S, Geffert S, Sehgal N, Falco FJE. Diagnostic accuracy of thoracic facet joint nerve blocks: An update of the assessment of evidence. Pain Physician 2012; 15:E483-E496.

41. Singh V, Manchikanti L, Shah RV, Dunbar EE, Glaser SE. Systematic review of thoracic discography as a diagnostic test for chronic spinal pain. Pain Physician 2008; 11:631-642.

42. Kuslich SD, Ulstrom CL, Michael CJ. The tissue origin of low back pain and sciatica: A report of pain response to tissue stimulation during operations on the lumbar spine using local anesthesia. Orthop Clin North Am 1991; 22:181-187.

43. Manchikanti L, Falco FJE, Boswell MV, Hirsch JA. Facts, fallacies, and politics of comparative effectiveness research: Part 1. Basic considerations. Pain Physician 2010; 13:E23-E54.

44. Manchikanti L, Falco FJE, Boswell MV Hirsch JA. Facts, fallacies, and politics of comparative effectiveness research: Part 2. Implications for interventional pain management. Pain Physician 2010; 13:E55-E79.

45. Manchikanti L, Helm II S, Hirsch JA. The evolution of the Patient-Centered Outcome Research Institute. J Neurointervent Surg 2012; 4:157-162.
46. Manchikanti L, Pampati V, Falco FJE, Hirsch JA. Growth of spinal interventional pain management techniques: Analysis of utilization trends and medicare expenditures 2000 to 2008. Spine (Phila Pa 1976) 2012 July 11 [Epub ahead of print].

47. Manchikanti L, Singh V, Caraway DL, Benyamin RM, Hirsch JA. Medicare physician payment systems: Impact of 2011 schedule on interventional pain management. Pain Physician 2011; 14:E5-E33.

48. Manchikanti L, Parr AT, Singh V, Fellows B. Ambulatory surgery centers and interventional techniques: $\mathrm{A}$ look at long-term survival. Pain Physician 2011; 14:E177-E215.

49. Manchikanti L, Pampati V, Boswell MV, Smith HS, Hirsch JA. Analysis of the growth of epidural injections and costs in the Medicare population: A comparative evaluation of 1997, 2002, and 2006 data. Pain Physician 2010; 13:199-212.

50. Manchikanti L, Pampati V, Singh V, Boswell MV, Smith HS, Hirsch JA. Explosive growth of facet joint interventions in the Medicare population in the United States: A comparative evaluation of 1997, 2002, and 2006 data. BMC Health Serv Res 2010; 10:84.

51. Abbott ZI, Nair KV, Allen RR, Akuthota VR. Utilization characteristics of spinal interventions. Spine J 2012; 1:35-43.

52. Centers for Medicare and Medicaid Services. Research, Statistics, Data \& Systems. www.cms.gov/Research-StatisticsData-and-Systems/Research-StatisticsData-and-Systems.html

53. Manchikanti L, Datta S, Gupta S, Munglani R, Bryce DA, Ward SP, Benyamin RM, Sharma ML, Helm II S, Fellows B, Hirsch JA. A critical review of the American Pain Society clinical practice guidelines for interventional techniques: Part 2. Therapeutic interventions. Pain Physician 2010; 13:E215-E264.

54. Chua NH, Gültuna I, Riezebos P, Beems $T$, Vissers KC. Percutaneous thoracic intervertebral disc nucleoplasty: Technical notes from 3 patients with painful thoracic disc herniations. Asian Spine J 2011; 5:15-19.

55. Kapural L, Sakic K, Boutwell K. Intradiscal biacuplasty (IDB) for the treatment of thoracic discogenic pain. Clin J Pain 2010; 26:354-357.

56. Moon SJ, Lee JK, Jang JW, Hur H, Lee $\mathrm{JH}, \mathrm{Kim} \mathrm{SH}$. The transdural approach for thoracic disc herniations: A technical note. Eur Spine ] 2010; 19:1206-1211.

57. Haufe SM, Mork AR, Pyne M, Baker RA. Percutaneous laser disc decompression for thoracic disc disease: Report of 10 cases. Int J Med Sci 2010; 7:155-159.

58. Ayhan S, Nelson C, Gok B, Petteys RJ, Wolinsky JP, Witham TF, Bydon A, Gokaslan ZL, Sciubba DM. Transthoracic surgical treatment for centrally located thoracic disc herniations presenting with myelopathy: A 5-year institutional experience. J Spinal Disord Tech 2010; 23:79-88.

59. Kaya A, Ozgocmen S. Thoracic disc herniation causing transient paraplegia coincident with epidural anesthesia: A case report. Cases ] 2009; 2:6228.

6o. Burke TG, Caputy AJ. Treatment of thoracic disc herniation: evolution toward the minimally invasive thoracoscopic technique. Neurosurg Focus 2000; 9: E9.

61. Manchikanti L, Pampati V, Hirsch JA. Analysis of utilization patterns of vertebroplasty and kyphoplasty in the Medicare population. J Neurointervent Surg 2012; Published Online July 7, 2012.

62. Brown CW, Deffer PA Jr, Akmakjian J, Donaldson DH, Brugman JL. The natural history of thoracic disc herniation. Spine (Phila Pa 1976) 1992; 17:S97-S102.

63. Manchikanti L, Datta S, Derby R, Wolfer LR, Benyamin RM, Hirsch JA. A critical review of the American Pain Society clinical practice guidelines for interventional techniques: Part 1. Diagnostic interventions. Pain Physician 2010; 13:E141E174.

64. Falco FJE, Datta S, Manchikanti L, Sehgal N, Geffert S, Singh V, Smith HS, Boswell MV. An updated review of diagnostic utility of cervical facet joint injections. Pain Physician 2012; 15:E807-E838

65. Falco FJE, Datta S, Sehgal N, Geffert $S$, Onyewu O, Singh V, Benyamin RM, Gupta S, Ward SP, Manchikanti L An update of systematic assessment of diagnostic accuracy of lumbar facet joint nerve blocks. Pain Physician 2012; 15:E868-Ego8.

66. Simopoulos TT, Manchikanti L, Singh V, Gupta S, Hameed H, Diwan S, Cohen SP. A systematic evaluation of prevalence and diagnostic accuracy of sacroiliac joint interventions. Pain Physician 2012; 15:Е305-E344.

67. Rubinstein SM, van Tulder M. A best-evidence review of diagnostic procedures for neck and low-back pain. Best Pract Res Clin Rheumatol 2008; 22:471-482.

68. Manchikanti L, Benyamin RM, Singh V, Falco FJE, Hameed H, Derby R, Wolfer LR, Helm II S, Cohen S. Systematic appraisal of accuracy of utility of lumbar discography in chronic low back pain. 
Pain Physician 2012; In Press.

69. Manchikanti L, Singh V, Pampati VS, Beyer CD, Damron KS. Evaluation of the prevalence of facet joint pain in chronic thoracic pain. Pain Physician 2002; 5:354359.

70. Onyewu O, Manchikanti L, Singh V, Geffert S, Helm II S, Hameed M, Falco FJE. An update of appraisal of accuracy and utility of cervical discography in chronic neck pain. Pain Physician 2012; 15:E777E806.

71. Wolfer L, Derby R, Lee JE, Lee SH. Systematic review of lumbar provocation discography in asymptomatic subjects with a meta-analysis of false-positive rates. Pain Physician 2008; 11:513-538.

72. Lindblom K. Diagnostic disc puncture of intervertebral discs in sciatica. Acta Orthop Scandinav 1948; 17:231-239.

73. Dandy W. Loose cartilage from intervertebral disc simulating tumor of the spinal cord. Arch Surg 1929; 19:660.

74. Mixter WJ, Barr JS. Rupture of the intervertebral disc with involvement of the spinal canal. N Eng J Med 1934; 211:210215.

75. Mixter WJ, Ayers JB. Herniation or rup ture of the intervertebral disc into the spinal canal. N Engl J Med 1935; 213:385395.

76. Yrjama M, Tervonen $\mathrm{O}$, Vanharanta $\mathrm{H}$. Ultrasonic imaging of lumbar discs combined with vibration pain provocation compared with discography in the diagnosis of internal anular fissures of the lumbar spine. Spine (Phila Pa 1976) 1996; 21:571-575.

77. Hancock MJ, Maher CG, Latimer J, Spindler MF, McAuleyJH, Laslett M, Bogduk N. Systematic review of tests to identify the disc, SIJ or facet joint as the source of low back pain. Eur Spine J 2007; 16:1539-1550.

78. Manchikanti L, Singh V, Derby R, Schultz DM, Benyamin RM, Prager JP, Hirsch JA. Reassessment of evidence synthesis of occupational medicine practice guidelines for interventional pain management. Pain Physician 2008; 11:393482.

79. Pang WW, Mok MS, Lin ML, Chang DP, Hwang $\mathrm{MH}$. Application of spinal pain mapping in the diagnosis of low back pain - analysis of 104 cases. Acta Anaesthesiol Sin 1998; 36:71-74.

8o. Manchikanti L, Singh V, Pampati V, Damron K, Barnhill R, Beyer C, Cash K. Evaluation of the relative contributions of various structures in chronic low back pain. Pain Physician 2001; 4:308-316.

81. Schwarzer AC, Aprill CN, Derby R, Fortin J, Kine G, Bogduk N. The prevalence and clinical features of internal disc disruption in patients with chronic low back pain. Spine (Phila Pa 1976) 1995; 20:18781883.

82. Bogduk N, Aprill C. On the nature of neck pain, discography and cervical zygapophysial joint blocks. Pain 1993; 54:213-217.

83. Crock HV. A reappraisal of intervertebral disc lesions. Med J Aust 1970; 1:983-989.

84. Ohnmeiss DD, Vanharanta H, Ekholm J. Degree of disc disruption and lower extremity pain. Spine (Phila Pa 1976) 1997; 22:1600-1605.

85. Wheeler AH, Murrey DB. Chronic lumbar spine and radicular pain: Pathophysiology and treatment. Curr Pain Headache Rep 2002; 6:97-105.

86. Falco FJ, Zhu J, Irwin L, Onyewu CO, Kim D. Thoracic discography. In Manchikanti L, Singh V (eds). Interventional Techniques in Chronic Spinal Pain. ASIPP Publishing, Paducah KY, 2007, pp 553-566.

87. Simmons EH, Segil CM. An evaluation of discography in the localization of symptomatic levels in discogenic disease of the spine. Clin Orthop 1975; 108:57-69.

88. Schellhas KP, Pollei SR, Dorwart RH. Thoracic discography. A safe and reliable technique. Spine (Phila Pa 1976) 1994; 19:2103-2109.

89. Winter RB, Schellhas KP. Painful adult thoracic Scheuermann's disease: Diagnosis by discography and treatment by combined arthrodesis. Am J Orthop 1996; 25:783-786.

90. Wood KB, Schellhas KP, Garvey TA, Aeppli D. Thoracic discography in healthy individuals. A controlled prospective study of magnetic resonance imaging and discography in asymptomatic and symptomatic individuals. Spine (Phila Pa 1976) 1999; 24:1548-1555.

91. Singh V. Thoracic discography. Pain Physician 2004; 7:451-458.

92. Hirsch C. An attempt to diagnose level of disc lesion clinically by disc puncture. Acta Orthop Scand 1948; 18:132-140.

93. Malmivaara A. Disc degeneration in the thoracolumbar junctional region. Evaluation by radiography and discography in autopsy. Acta Radiol 1987; 28:755-760.

94. Skubic JW, Kostuik JP. Thoracic pain syndromes and thoracic disc herniation. In Frymoyer JW (ed). The Adult Spine: Principles and Practice. Raven Press, New York,
1991, pp 1443-1461.

95. Whitecloud TS, Seago RA. Cervical discogenic syndrome: Results of operative intervention in patients with positive discography. Spine (Phila Pa 1976) 1987; 12:313-316.

96. Zucherman J, Derby R, Hsu K, Picetti G, Kaiser J, Schofferman J, Goldthwaite N, White A. Normal magnetic resonance imaging with abnormal discography. Spine (Phila Pa 1976) 1988; 13:1355-1359.

97. Weinstein J, Claverie W. Gibson S. The pain of discography. Spine (Phila Pa 1976) 1998; 13:1344-1348.

98. Bogduk N, Modic MT. Lumbar discography. Spine (Phila Pa 1976) 1996; 21:402404 .

99. Bland JH. Diagnosis of thoracic pain syndromes. In Giles LGF, Singer KP (eds). Clinical Anatomy and Management of Thoracic Spine Pain, Vol. 2. Butterworth-Heinemann, Oxford, 2000, pp 145-156.

100. Mclnerney J, Ball PA. The pathophysiology of thoracic disc disease. Neurosurg Focus 2000; 9:el.

101. Cloward RB. Anterior herniation of a ruptured lumbar intervertebral disk; comments on the diagnostic value of the diskogram. AMA Arch Surg 1952; 64:457-463.

102. Lindblom K. Technique and results in myelography and disc puncture. Acta Radiol 1950; 34:321-330.

103. Antti-Poika I, Soini J, Tallroth K, Yrjonen T, Konttinen YT. Clinical relevance of discography combined with CT scanning. A study of 100 patients. J Bone Joint Surg Br 1990; 72:480-485.

104. Jensen MC, Brant-Zawadzki MN, Obuchowski N, Modic MT, Malkasian D, Ross JS. Magnetic resonance imaging of the lumbar spine in people without back pain. N Engl J Med 1994; 331:69-73.

105. Horton WC, Daftari TK. Which disc as visualized by magnetic resonance imaging is actually a source of pain? A correlation between magnetic resonance imaging and discography. Spine (Phila Pa 1976) 1992; 17:S164-S171.

106. Boden SD, Davis DO, Dina TS, Patronas $\mathrm{NJ}$, Wiesel SW. Abnormal magnetic-resonance scans of the lumbar spine in asymptomatic subjects. A prospective investigation. J Bone Joint Surg Am 1990; 72:403-408.

107. Wood KB, Blair JM, Aepple DM, Schendel MJ, Garvey TA, Gundry CR, Heithoff KB. The natural history of asymptomatic thoracic disc herniations. Spine (Phila Pa 
1976) 1997; 22:525-529.

108. Smith GW, Nichols P Jr. The technique of cervical discography. Radiology 1957; 68:718-720.

109. Derby R, Sang-Heon L, Chen Y. Discograms: Cervical, thoracic, and lumbar. Tech Reg Anesth Pain Manag 2005; 9:97105.

110. Buenaventura RM, Shah RV, Patel V, Benyamin R, Singh V. Systematic review of discography as a diagnostic test for spinal pain: An update. Pain Physician 2007; 10:147-164.

111. Shah RV, Everett C, McKenzie-Brown A, Sehgal N. Discography as a diagnostic test for spinal pain: A systematic and narrative review. Pain Physician 2005; 8:187-209.

112. Merskey H, Bogduk N. Thoracic discogenic pain. In Classification of Chronic Pain. Descriptions of Chronic Pain Syndromes and Definition of Pain Terms, 2nd ed. International Association for the Study of Pain. IASP Press, Seattle, 1994, p 116.

113. Merskey H, Bogduk N. Lumbar discogenic pain. In Classification of Chronic Pain. Descriptions of Chronic Pain Syndromes and Definition of Pain Terms, 2nd ed. International Association for the Study of Pain. IASP Press, Seattle, 1994, pp 180-181.

114. Merskey H, Bogduk N. Cervical discogenic pain. In Classification of Chronic Pain. Descriptions of Chronic Pain Syndromes and Definition of Pain Terms, 2nd ed. International Association for the Study of Pain. IASP Press, Seattle, 1994, p 108.

115. Zhang YH, Zhao CQ, Jiang LS, Chen XD, Dai LY. Modic changes: a systematic review of the literature. Eur Spine ] 2008; 17:1289-1299.

116. Bogduk N. Thoracic disc stimulation (provocation discography). In Practice Guidelines for Spinal Diagnostic and Treatment Procedure. International Spine Intervention Society (ISIS), San Francisco, 2004, pp 287-294.

117. Bogduk N. Cervical disc stimulation (provocation discography). In Practice Guidelines for Spinal Diagnostic and Treatment Procedures. International Spine Intervention Society (ISIS), San Francisco, 2004, pp 95-111.

118. Bogduk N. Lumbar disc stimulation (provocation discography). In Practice Guidelines for Spinal Diagnostic and Treatment Procedures. International Spine Intervention Society (ISIS), San Francisco, 2004, pp 20-46.
119. Laslett M, Aprill CN, McDonald B, Oberg B. Clinical predictors of lumbar provocation discography: A study of clinical predictors of lumbar provocation discography. Eur Spine J 2006; 15:1473-1484.

120. Laslett M, Oberg B, Aprill CN, McDonald B. Centralization as a predictor of provocation discography results in chronic low back pain, and the influence of disability and distress on diagnostic power. Spine ] 2005; 5:370-380.

121. Berg AO, Allan JD. Introducing the third U.S. Preventive Services Task Force. Am J Prev Med 2001; 20:21-35.

122. West S, King V, Carey TS, Lohr KN, McKoy N, Sutton SF, Lux L. Systems to Rate the Strength of Scientific Evidence, Evidence Report, Technology Assessment No. 47. AHRQ Publication No. O2Eo16. Rockville, MD: Agency for Healthcare Research and Quality, 2002. www. thecre.com/pdf/ahrq-system-strength. pdf

123. Manchikanti L, Derby R, Wolfer LR, Singh V, Datta S, Hirsch JA. Evidencebased medicine, systematic reviews, and guidelines in interventional pain management: Part 5. Diagnostic accuracy studies. Pain Physician 2009; 12:517-540.

124. Bossuyt PM, Reitsma JB, Bruns DE, Gatsonis CA, Glasziou PP, Irwig LM, Lijmer JG, Moher D, Rennie D, de Vet HC; Standards for Reporting of Diagnostic Accuracy. Towards complete and accurate reporting of studies of diagnostic accuracy: The STARD Initiative. Ann Intern Med 2003; 138:40-44.

125. Whiting P, Rutjes A, Reitsma J, Bossuyt P, Kleijnen J. The Development of QUADAS: A tools for the quality assessment of studies of diagnostic accuracy included in systematic reviews. BMC Med Res Methodol 2003; 3:25.

126. Lucas N, Macaskill P, Irwig L, Moran R, Bogduk N. Reliability of physical examination for diagnosis of myofascial trigger points: A systematic review of the literature. Clin J Pain 2009; 25:80-89.

127. Lucas NP, Macaskill P, Irwig L, Bogduk $\mathrm{N}$. The development of a quality appraisal tool for studies of diagnostic reliability (QAREL). J Clin Epidemiol 2010; 63:854-861.

128. Hestboek L, Leboeuf-Yde C. Are chiropractic tests for the lumbo-pelvic spine reliable and valid? A systematic critical literature review. J Manipulative Physiol Ther 2000; 23:258-275.

129. Hollerwoger D. Methodological quali- ty and outcomes of studies addressing manual cervical spine examinations: A review. Man Ther 2006; 11:93-98.

130. May S, Littlewook C, Bishop A. Reliability of procedures used in the physical examination of non-specific low back pain: A systematic review. Aust J Physiother 2006; 52:91-102.

131. Stochkendahl MJ, Christensen HW, Hartvigsen J, Vach W, Haas M, Hestbaek L, Adams A, Bronfort G. Manual examination of the spine: $A$ systematic critical literature review of reproducibility.] Manipulative Physiol Ther 2006; 29:475-485, 485.e1-10.

132. van Trijffel $E$, Anderegg $Q$, Bossuyt PM, Lucas C. Inter-examiner reliability of passive assessment of intervertebral motion in the cervical and lumbar spine: A systematic review. Man Ther 2005; 10:256-269.

133. van Tulder M, Furlan A, Bombardier C, Bouter L; Editorial Board of the Cochrane Collaboration Back Review Group. Updated method guidelines for systematic reviews in the Cochrane Collaboration Back Review Group. Spine (Phila Pa 1976) 2003; 28:1290-1299.

134. Staal JB, de Bie R, de Vet HC, Hildebrandt J, Nelemans P. Injection therapy for subacute and chronic low-back pain. Cochrane Database Syst Rev 2008; 3:CDoo1824.

135. Liberati A, Altman DG, TetzlaffJ, Mulrow C, Gøtzsche PC, loannidis JP, Clarke M, Devereaux PJ, Kleijnen J, Moher D. The PRISMA statement for reporting systematic reviews and meta-analyses of studies that evaluate health care interventions: Explanation and elaboration. Ann Intern Med 2009; 151:W65-W94.

136. Harris RP, Helfand M, Woolf SH, Lohr KN, Mulrow CD, Teutsch SM, Atkins D; Methods Work Group, Third US Preventive Services Task Force. Current methods of the US Preventive Services Task Force. Am J Prevent Med 2001; 20:21-35.

137. Chou R, Huffman L. Guideline for the Evaluation and Management of Low Back Pain: Evidence Review. American Pain Society, Glenview, IL, 2009.

www.ampainsoc.org/pub/pdf/LBPEvidRev.pdf

138. Schellhas KP, Pollei SR. The role of discography in the evaluation of patients with spinal deformity. Orthop Clin North Am 1994; 25:265-273.

139. Simmons JW, Emery SF, McMillin JN, Landa D, Kimmich SJ. Awake discography. A comparison study with magnetic resonance imaging. Spine (Phila Pa 1976) 1991; 16:S216-S221. 
140. Walsh TR, Weinstein JN, Spratt KF, Lehmann TR, Aprill C, Sayre H. Lumbar discography in normal subjects. A controlled, prospective study. J Bone Joint Surg Am 1990; 72:1081-1088.

141. Fluke M. To the Editor. Thoracic discography: A safe and reliable technique. Spine (Phila Pa 1976) 1995; 20:1740.

142. Schellhas KP. In response to thoracic discography: A safe and reliable technique. Spine (Phila Pa 1976) 1995; 20:1740-1741.

143. Weinstein JN, Walsh TR, Spratt KF, Lehman TR, Sayre H. Lumbar discography: A controlled, prospective study of normal volunteers to determine the false-positive rate. Orthopaedic Transactions 1989; 13:647-648.

144. Knottnerus JA, van Weel C, Muris JW. Evaluation of diagnostic procedures. BMJ 2002; 324:477-480.

145. Saal JS. General principles of diagnostic testing as related to painful lumbar spine disorders. Spine (Phila Pa 1976) 2002; 27:2538-2545.

146. Derby R, Kim BJ, Lee SH, Chen Y, Seo KS, Aprill C. Comparison of discographic findings in asymptomatic subject discs and negative discs of chronic LBP patients: Can discography distinguish asymptomatic discs among morphologically abnormal discs? Spine J 2005; 5:389-394.

147. Schellhas KP, Smith MD, Gundry CR, Pollei SR. Cervical discogenic pain. Prospective correction of magnetic resonance imaging and discography in asymptomatic subjects and pain sufferers. Spine (Phila Pa 1976) 1996; 21:300-311.

148. Klafta LA Jr, Collis JS Jr. The diagnostic inaccuracy of the pain response in cervical discography. Cleveland Clin Q 1969; 36:35-39.

149. Cohen S, Hurley RW. The ability of diagnostic spinal injections to predict surgical outcomes. Pain Med 2007; 105:17561775 .

150. Derby R, Lee SH, Kim BJ, Chen Y, Aprill C, Bogduk N. Pressure-controlled lumbar discography in volunteers without low back symptoms. Pain Med 2005; 6:213-221.

151. Carragee EJ, Alamin TF, Carragee JM. Low-pressure positive discography in subjects asymptomatic of significant low back pain illness. Spine (Phila $\mathrm{Pa}$ 1976) 2006; 31:505-509.

152. Carragee EJ, Chen Y, Tanner CM, Hayward C, Rossi M, Hagle C. Can discography cause long-term back symptoms in previously asymptomatic subjects?
Spine (Phila Pa 1976) 2000; 25:1803-1808.

153. Carragee EJ, Barcohana B, Alamin T, van den Haak E. Prospective controlled study of the development of lower back pain in previously asymptomatic subjects undergoing experimental discography. Spine (Phila Pa 1976) 2004; 29:1112-1117.

154. Derby R. Lumbar discometry. Newsletter of International Spine Injection Society 1993; 1:8-17.

155. Derby R, Howard MW, Grant JM, Lettice JJ, Van Peteghem PK, Ryan DP. The ability of pressure-controlled discography to predict surgical and nonsurgical outcomes. Spine (Phila Pa 1976) 1999; 24:364-371; discussion 371-362.

156. Shin D, Kim H, Jung J, Sin D, Lee J. Diagnostic relevance of pressure-controlled discography. J Korean Med Sci 2006; 21:911-916.

157. Manchikanti L, Singh V, Pampati VS, Fellows B, Beyer C, Damron K, Cash KA. Provocative discography in low back pain patients with or without somatization disorder: A randomized prospective evaluation. Pain Physician 2001; 4:227239.

158. Fagan A, Moore R, Vernon Roberts B, Blumbergs $P$, Fraser $R$. The innervation of the intervertebral disc: A quantitative analysis. Spine (Phila Pa 1976) 2003; 28:2570-2576.

159. Ashton IK, Roberts S, Jaffray DC, Polak JM, Eisenstein SM. Neuropeptides in the human intervertebral disc. ] Orthop Res 1994; 12:186-192.

160. Roofe PG. Innervation of annulus fibrosis and posterior longitudinal ligament. Arch Neurol Psych 1940; 44:100-103.

161. Malinsky J. The ontogenetic development of nerve trigeminations in the intervertebral discs of man. Acta Anat 1959; 38:96-113.

162. Roberts S, Eisenstein SM, Menage J, Evans $\mathrm{EH}$, Ashton IK. Mechanoreceptors in intervertebral discs. Spine (Phila Pa 1976) 1995; 24:2645-2651.

163. Freemont AJ, Watkins A, Le Maitre C, Baird $P$, Jeziorska $M$, Knight MT, Ross ER, O'Brien JP, Hoyland JA. Nerve growth factor expression and innervation of the painful intervertebral disc. J Pathol 2002; 197:286-292.

164. Burke JG, G Watson RW, Conhyea D, McCormack D, Dowling FE, Walsh MG, Fitzpatrick JM. Human nucleus pulposus can respond to a pro-inflammatory stimulus. Spine (Phila Pa 1976) 2003; 28:2685-2693
165. Stilwell DL. The nerve supply of the vertebral column and its associated structures in the monkey. Anat Rec 1956; 125:139-169.

166. Kojima Y, Maeda T, Arai R, Shichikawa K. Nerve supply to the posterior longitudinal ligament and the intervertebral disc of the rat vertebral column as studied by acetylcholinesterase histochemistry. II. Regional differences in the distribution of the nerve fibres and their origins. J Anat 1990; 169:247-255.

167. Forsythe WB, Ghoshal NG. Innervation of the canine thoracolumbar vertebral column. Anat Rec 1984; 208:57-63.

168. Ohtori S, Takahashi K, Yamagata M, Sameda H, Moriya H, Chiba T, Takahashi $Y$. Neurones in the dorsal root ganglia of $\mathrm{T}_{13}, \mathrm{~L}_{1}$ and $\mathrm{L}_{2}$ innervate the dorsal portion of lower lumbar discs in rats. A study using dil, an anterograde neurotracer. J Bone Joint Surg Br 2001; 83:1191-1194.

169. Manchikanti L, Pampati V, Damron KS. The role of placebo and nocebo effects of perioperative administration of sedatives and opioids in interventional pain management. Pain Physician 2005; 8:349-355.

170. Manchikanti L, Giordano J, Fellows B, Hirsch JA. Placebo and nocebo in interventional pain management: $A$ friend or a foe - or simply foes? Pain Physician 2011; 14:E157-E175.

171. Chou R, Atlas SJ, Loeser JD, Rosenquist RW, Stanos SP. Guideline warfare over interventional therapies for low back pain: Can we raise the level of discourse? J Pain 2011; 12:833-839.

172. Manchikanti L, Benyamin RM, Falco FJE, Caraway DL, Datta S, Hirsch JA. Guidelines warfare over interventional techniques: Is there a lack of discourse or straw man? Pain Physician 2012; 15:E1E26.

173. Chua NH, Vissers KC, Arendt-Nielsen L, Wilder-Smith $\mathrm{OH}$. Do diagnostic blocks have beneficial effects on pain processing? Reg Anesth Pain Med 2011; 36:317321.

174. Lyby PS, Forsberg JT, Asli O, Flaten MA. Induced fear reduces the effectiveness of a placebo intervention on pain. Pain 2012; 153:1114-1121.

175. Hebelka H, Gaulitz A, Nilsson A, Holm $S$, Hansson T. The transfer of disc pressure to adjacent discs in discography: $\mathrm{A}$ specificity problem? Spine (Phila Pa 1976) 2010; 35:E1025-E1029.

176. Häuser W, Bartram C, Bartram-Wunn 
E, Tölle T. Adverse events attributable to nocebo in randomized controlled drug trials in fibromyalgia syndrome and painful diabetic peripheral neuropathy: Systematic review. Clin J Pain 2012; 28:437-451.

177. Manchikanti L, Singh V, Cash KA, Pampati V, Damron KS, Boswell MV. Effect of fluoroscopically guided caudal epidural steroid or local anesthetic injections in the treatment of lumbar disc herniation and radiculitis: $A$ randomized, controlled, double blind trial with a two-year follow-up. Pain Physician 2012; 15:273-286.

178. Manchikanti L, Singh V, Cash KA, Pampati $V$, Datta $S$. Management of pain of post lumbar surgery syndrome: Oneyear results of a randomized, double double-blind, active controlled trial of fluoroscopic caudal epidural injections. Pain Physician 2010; 13:509-521.

179. Manchikanti L, Cash RA, McManus CD, Pampati V, Fellows B. Fluoroscopic caudal epidural injections with or without steroids in managing pain of lumbar spinal stenosis: One year results of randomized, double-blind, active-controlled trial. J Spinal Disord Tech 2012; 25:226-234.

180. Manchikanti L, Cash KA, McManus CD, Pampati V, Benyamin R. Fluoroscopic lumbar interlaminar epidural injections in managing chronic lumbar axial or discogenic pain. J Pain Res 2012; 5:301311.

181. Manchikanti L, Cash KA, McManus CD, Damron KS, Pampati V, Falco FJE. Lumbar interlaminar epidural injections in central spinal stenosis: Preliminary results of a randomized, double-blind, active control trial. Pain Physician 2012; 15:51-63.

182. Manchikanti L, Cash KA, Pampati V, Malla Y. Fluoroscopic cervical epidural injections in chronic axial or disc-related neck pain without disc herniation, facet joint pain, or radiculitis. J Pain Res 2012; 227-236.

183. Manchikanti L, Cash KA, Pampati V, Wargo BW, Malla Y. Management of chronic pain of cervical disc herniation and radiculitis with fluoroscopic cervical interlaminar epidural injections. Int J Med Sci 2012; 9:424-434.

184. Manchikanti L, Malla Y, Cash KA, McManus CD, Pampati V. Fluoroscopic epidural injections in cervical spinal stenosis: Preliminary results of a randomized, double-blind, active control trial. Pain Physician 2012; 15:E59-E70.
185. Manchikanti L, Malla Y, Cash KA, McManus CD, Pampati V. Fluoroscopic cervical interlaminar epidural injections in managing chronic pain of cervical postsurgery syndrome: Preliminary results of a randomized, double-blind active control trial. Pain Physician 2012; 15:1326.

186. Manchikanti L, Singh V, Falco FJE, Cash KA, Fellows B. Comparative outcomes of a 2-year follow-up of cervical medial branch blocks in management of chronic neck pain: A randomized, double-blind controlled trial. Pain Physician 2010; 13:437-450.

187. Manchikanti L, Singh V, Falco FJE, Cash KA, Pampati V. Evaluation of lumbar facet joint nerve blocks in managing chronic low back pain: A randomized, doubleblind, controlled trial with a 2-year follow-up. Int J Med Sci 2010; 7:124-135.

188. Pham Dang C, Lelong A, Guilley J, Nguyen JM, Volteau C, Venet G, Perrier $C$, Lejus C, Blanloeil Y. Effect on neurostimulation of injectates used for perineural space expansion before placement of a stimulating catheter: Normal saline versus dextrose $5 \%$ in water. Reg Anesth Pain Med 2009; 34:398-403.

189. Carette S, Leclaire R, Marcoux S, Morin F, Blaise GA, St-Pierre A, Truchon R, Parent $F$, Levesque J, Bergeron V, Montminy $P$, Blanchette $C$. Epidural corticosteroid injections for sciatica due to herniated nucleus pulposus. N Engl J Med 1997; 336:1634-1640.

190. Bhatia MT, Parikh LC). Epidural saline therapy in lumbo-sciatic syndrome. J Indian Med Assoc 1966; 47:537-542.

191. Gupta AK, Mital VK, Azmi RU. Observations of the management of lumbosciatic syndromes (sciatica) by epidural saline. J Indian Med Assoc 1970; 54:194-196.

192. Wittenberg RH, Greskötter KR, Steffen $R$, Schoenfeld BL. Is epidural injection treatment with hypertonic saline solution in intervertebral disk displacement useful? (The effect of $\mathrm{NaCl}$ solution on intervertebral disk tissue). Z Orthop Ihre Grenzgeb 1990; 128:223-226.

193. Pasqualucci A, Varrassi G, Braschi A, Peduto VA, Brunelli A, Marinangeli $F$, Gori F, Colò F, Paladín A, Mojoli F. Epidural local anesthetic plus corticosteroid for the treatment of cervical brachial radicular pain: Single injection verus continuous infusion. Clin J Pain 2007; 23:551-557.

194. Arner S, Lindblom U, Meyerson BA, Molander $C$. Prolonged relief of neuralgia after regional anesthetic block. A call for further experimental and systematic clinical studies. Pain 1990; 43:287-297.

195. Cassuto J, Sinclair R, Bonderovic M. Anti-inflammatory properties of local anesthetics and their present and potential clinical implications. Acta Anaesthesiol Scand 2006; 50:265-282.

196. Lavoie PA, Khazen T, Filion PR. Mechanisms of the inhibition of fast axonal transport by local anesthetics. Neuropharmacology 1989; 28:175-181.

197. Melzack R, Coderre TJ, Katz J, Vaccarino AL. Central neuroplasticity and pathological pain. Ann N Y Acad Sci 2001; 933:157-174.

198. Sharma SK, Jones JO, Zeballos PP, Irwin SA, Martin TW. The prevention of discitis during discography. Spine J 2009; 9:936-943.

199. Chu CR, Izzo NJ, Papas NE, Fu FH. In vitro exposure to $0.5 \%$ bupivacaine is cytotoxic to bovine articular chondrocytes. Arthroscopy 2006; 22:693-699.

200. Chu CR, Izzo NJ, Coyle CH, Papas NE, Logar A. The in vitro effects of bupivacaine on articular chondrocytes. J Bone Joint Surg Br 2008; 90:814-820.

201. Grishko V, Xu M, Wilson G, Pearsall AW. Apoptosis and mitochondrial dysfunction in human chondrocytes following exposure to lidocaine, bupivacaine, and ropivacaine. J Bone Joint Surg Am 2010; 92:609-618.

202. Piper SL, Kim HT. Comparison of ropivacaine and bupivacaine toxicity in human articular chondrocytes. J Bone Joint Surg Am 2008; 90:986-991.

203. Moon JH, Kuh SU, Park HS, Kim KH, Park JY, Chin DK, Kim KS, Cho YE. Triamcinolone decreases bupivacaine toxicity to intervertebral disc cell in vitro. Spine 2012 Jul 21. [Epub ahead of print]

204. Lee H, Sowa G, Vo N, Vadala G, O'Connell S, Studer R, Kang J. Effect of bupivacaine on intervertebral disc cell viability. Spine J 2010; 10:159-166.

205. Quero L, Klawitter M, Nerlich AG, Leonardi $M$, Boos N, Wuertz K. Bupivacaine-the deadly friend of intervertebral disc cells?. Spine ] 2011; 11:46-53.

206. Wang D, Vo NV, Sowa GA, Hartman RA, Ngo K, Choe SR, Witt WT, Dong Q, Lee JY, Niedernhofer LJ, Kang JD. Bupivacaine decreases cell viability and matrix protein synthesis in an intervertebral disc organ model system. Spine J 2011; 11:139-146.

207. Tian W, Qi H. Association between intervertebral disc degeneration and disturbances of blood supply to the verte- 
brae. Chin Med J (Engl) 2010; 123:239-243.

208. Werner BC, Hogan MV, Shen FH. Candida lusitaniae discitis after discogram in an immunocompetent patient. Spine J 2011; 11:E1-E6.

209. Mao HJ, Chen QX, Han B, Li FC, Feng J, Shi ZL, Lin M, Wang J. The effect of injection volume on disc degeneration in a rat tail model. Spine (Phila Pa 1976) 2011; 36:E1062-E1069.

210. Pobiel RS, Schellhas KP, Pollei SR, Johnson BA, Golden MJ, Eklund JA. Diskography: Infectious complications from a series of 12,634 cases. AJNR Am J Neuroradiol 2006; 27:1930-1932.

211. Miyagi M, Ishikawa T, Orita S, Eguchi $Y$, Kamoda H, Arai G, Suzuki M, Inoue G, Aoki Y, Toyone T, Takahashi K, Ohtori S. Disk injury in rats produces persistent increases in pain-related neuropeptides in dorsal root ganglia and spinal cord glia but only transient increases in inflammatory mediators: Pathomechanism of chronic diskogenic low back pain. Spine (Phila Pa 1976) 2011; 36:22602266.
212. Cuellar VG, Cuellar JM, Vaccaro AR, Carragee EJ, Scuderi GJ. Accelerated degeneration after failed cervical and lumbar nucleoplasty. J Spinal Disord Tech 2010; 23:521-524.

213. Carragee EJ, Don AS, Hurwitz EL, Cuellar JM, Carrino JA, Herzog R. 2009 ISSLS Prize Winner: Does discography cause accelerated progression of degeneration changes in the lumbar disc: a tenyear matched cohort study. Spine (Phila Pa 1976) 2009; 34:2338-2345.

214. Carragee EJ, Barcohana B, Alamin T, van den Haak E. Prospective controlled study of the development of lower back pain in previously asymptomatic subjects undergoing experimental discography. Spine (Phila Pa 1976) 2004; 29:1112-1117.

215. latridis JC, Hecht AC. Commentary: Does needle injection cause disc degeneration? News in the continuing debate regarding pathophysiology associated with intradiscal injections. Spine J 2012; 12:336-338.
216. Gruber HE, Rhyne AL, Hansen KJ, Phillips RC, Hoelscher GL, Ingram JA, Norton HJ, Hanley EN Jr. Deleterious effects of discography radiocontrast solution on human annulus cell in vitro: changes in cell viability, proliferation, and apoptosis in exposed cells. Spine J 2012; 12:329-335.

217. Manchikanti L, Malla Y, Wargo BW, Cash KA, McManus CD, Damron KS, Jackson SD, Pampati V, Fellows B. A prospective evaluation of bleeding risk of interventional techniques in chronic pain. Pain Physician 2011; 14:317-329.

218. Manchikanti L, Malla Y, Wargo BW, Fellows B. Infection control practices (safe injection and medication vial utilization) for interventional techniques: Are they based on relative risk management or evidence? Pain Physician 2011; 14:425434 .

219. Manchikanti L, Malla Y, Wargo BW, Fellows B. Preoperative fasting before interventional techniques: Is it necessary or evidence-based? Pain Physician 2011; 14:459-467. 
